\title{
PENGARUH NILAI-NILAI MULTIKULTURAL TERHADAP MENUMBUHKEMBANGKAN KARAKTER NASIONALIS
}

\author{
Rahmat \\ Lu'lu' il Maknuun \\ Institut Pesantren KH. Abdul Chalim Mojokerto \\ rahmatpaikhac@gmail.com, luluilmaknuun92@gmail.com
}

\begin{abstract}
ABSTRAK
Setiap individu dituntut untuk berkarakter baik dalam kehidupan sehariharinya. Sedangkan pendidikan karakter merupakan tanggungjawab setiap individu itu pula, yang pada konteks ini, dapat dimulai dari lingkungan sekitar baik di rumah maupun dalam lingkungan pendidikan sekolah. Dengan demikian, maka perlu adanya identifikasi terkait faktor-faktor yang sangat mempengaruhi terkait perbaikan karakter, khususnya karakter nasionalisme. Artikel ini mencoba untuk menjelaskan pengaruh dari nilai-nilai multikultural terhadap menumbuhkembangkan karakter nasionalis bagi peserta didik. Sebab, pemilihan nilai-nilai multikultural yang tepat akan sangat mempengaruhi terhadap tumbuhkembangknya karakter nasionalis bagi peserta didik. Dengan metode kuantitatif, memanfaatkan teknik survei dalam bentuk kuisioner. Kemudian, kuisioner tersebut disampaikan kepada peserta didik kelas XII Madrasah Aliyah Bertaraf Internasional (MBI) Amanatul Ummah Mojokerto untuk kemudian dapat mengetahui pengaruh nilai-nilai multikultural terhadap menumbuhkembangakan karakter nasionalis.
\end{abstract}

Kata kunci: Nilai-nilai Multikulutral, Menumbuhkembangkan karakter Nasionalis

\section{ABSTRACT}

Every individual is required to have good character in their daily lives. Whereas character education is the responsibility of each individual too, which in this context, can be started from the surrounding environment both at home and in the school education environment. Thus, it is necessary to identify related factors that greatly affect the improvement of character, especially the character of nationalism. This article tries to explain the influence of multicultural values on developing nationalist characters for students. Therefore, the selection of appropriate multicultural values will greatly influence the growth of nationalist character for students. With quantitative methods, utilizing survey techniques in the form of questionnaires. Then, the questionnaire was submitted to the students of class XII International Standard Madrasah Aliyah (MBI) Amanatul Ummah Mojokerto to then be able to find out the influence of multicultural values on the development of nationalist character.

Keywords: Multicultural values, Developing nationalist character

\section{PENDAHULUAN}


Indonesia mempunyai cita-cita untuk menciptakan generasi muda yang berkarakter sesuai yang telah dicanangkan oleh Kementrian Pendidikan nasional dalam Renstra 20102014. Negara menerapkan Pendidikan karakter dari Pendidikan sejak dini sampai dengan perguruan tinggi ${ }^{1}$. Dalam menumbuhkembangkan pendidikan karakter dimulai dari didikan orangtua, keluarga dan lingkungan internal maupun eksternal ${ }^{2}$. Sebuah keluarga yang dipimpin seorang ayah dan dibantu soerang ibu merupakan pendidikan pertama bagi seorang peserta didik ${ }^{3}$. Keluarga yang harmonis juga ikut andil sebagai faktor dalam menumbuhkembangkan karakter. Lingkungan juga tidak pentingnya dari penentu untuk menumbuhkembangkan karakter nasionalis ${ }^{4}$.

Bangsa Indonesia terkenal akan kulturnya yang beranekaragam atau disebut juga multikultur. Tercatat Indonesia Iadalah sebuah bangsa yang plural dan Multikultural. Seperti dalam sebuah penelitian tentang etnologis, kabarnya sekitaran 740 etnis (Wikipedia: 2019) 400 bahasa, 6 agama dan 17 ribu pulau yang dimiliki oleh bangsa Indonesia ${ }^{5}$.

Keluhuran nilai-nilai kulturnya telah menuntun bangsa ini menjelma menjadi negara yang tingkat toleransinya tinggi ${ }^{6}$. Namun dalam upaya tersebut bangsa ini diguncang secara beruntun dengan teror bom pada tahun 1996-1997 di Sanggau Ledo Kalbar, tahun 1999 Ambon dan Maluku, tahun 2000 di Sampit Kalteng, Bom di Bali dan banyak lagi ${ }^{7}$. Dan kini berkembang semakin kompleks seperti fenomena upaya makar, (Kompas Tv: 2019) anti pancasila, terosisme, korupsi E-KTP.

\footnotetext{
1 Rahmat Rahmat, 'Model Pembelajaran Pendidikan Agama Islam Berlandaskan Multikultural (Telaah Implikasi Model Cooperative Learning Di Perguruan Tinggi)', Jurnal Andragogi 1, no. 2 (14 November 2019): 6885, http://riset.unisma.ac.id/index.php/ja/article/view/5290; Abdullah Aly, Pendidikan Islam Multikultural Di Pesantren: Telaah Terhadap Kurikulum Pondok Pesantren Modern Islam Assalam Surakarta, Cet. 1 (Yogyakarta: Pustaka Pelajar, 2011).

${ }^{2}$ Asror Baisuki and Ta'rif Ta'rif, ‘Penanaman Karakter Moderat Di Ma'had Aly Situbondo', EDUKASI: Jurnal Penelitian Pendidikan Agama Dan Keagamaan 15, no. 3 (31 December 2017), https://doi.org/10.32729/edukasi.v15i3.456; Muhammad Anas Ma'arif, 'Analisis Strategi Pendidikan Karakter Melalui Hukuman Preventif', Ta'allum: Jurnal Pendidikan Islam 6, no. 1 (6 March 2018): 31-56, https://doi.org/10.21274/taalum.2018.6.1.31-56; Andika Aprilianto and Wahyuni Mariana, 'Permainan Edukasi (Game) Sebagai Strategi Pendidikan Karakter', Nazhruna: Jurnal Pendidikan Islam 1, no. 1 (5 September 2018): 13958, https://doi.org/10.31538/nzh.v1i1.47.

${ }^{3}$ Idi Warsah, ‘Pendidikan Keluarga Muslim Di Tengah Masyarakat Multi Agama: Antara Sikap Keagamaan Dan Toleransi (studi Di Desa Suro Bali Kepahiang-Bengkulu)', Edukasia : Jurnal Penelitian Pendidikan Islam 13, no. 1 (25 July 2018): 1-24, https://doi.org/10.21043/edukasia.v13i1.2784.

${ }^{4}$ Muhammad Anas Ma`arif and Muhammad Husnur Rofiq, 'The Role of Islamic Education Teachers in Improving the Character of Nationalism in Boarding School', EDUKASI: Jurnal Pendidikan Islam 6, no. 1 (21 June 2018): 064-078, https://doi.org/10.5281/edukasi.v6i1.323.

${ }^{5}$ Suryadinata, Penduduk Indonesia (Jakarta: LP3ES, 2003), 102.

${ }^{6}$ Muhammad Hifdil Islam, 'Tolerance Limitation in Facing Religious Diversity Based on the Teaching of Islam', Nazhruna: Jurnal Pendidikan Islam 3, no. 1 (7 February 2020): 1-13, https://doi.org/10.31538/nzh.v3i1.483; Puspo Nugroho, 'Internalization of Tolerance Values in Islamic Education', Nadwa 12, no. 2 (7 January 2019): 197228, https://doi.org/10.21580/nw.2018.12.2.2397.

7 Raihani, Pendidikan Islam Dalam Masyarakat Multikultural, Cet. 1 (Yogyakarta: Pustaka Pelajar, 2016); Hamlan Andi Baso Malla, ‘Pembelajaran Pendidikan Agama Islam Berbasis Multikultural Humanistik Dalam Membentuk Budaya Toleransi Peserta Didik Di SMA Negeri Model Madani Palu, Sulawesi Tengah', INFERENSI: Jurnal Penelitian Sosial Keagamaan 11, no. 1 (1 June 2017): 163-86, https://doi.org/10.18326/infsl3.v11i1.163-186.
} 
Suku, etnis dan agama (UU Sisdiknas, 2013) menjadi bahan propaganda ${ }^{8}$ di setiap pemilihan kepala daerah, aksi demo secara masif dari organisasi Islam, sampai-sampai munculnya intervensi pemerintah tentang sertifikasi penceramah (Lukman Hakim, Metro Tv: 2017) adapun wacana ini dirasa perlu karena walau rumah ibadah tersebut hasil otonomi masyarakat namun pemerintah tidak dapat tinggal diam apabila rumah ibadah dijadikan sebagai sarana menebar sara, serta pembubaran ceramah beberapa tokoh agama yang ditengarai mendukung berdirinya khilafah yang berujung pada pembubaran organisasi Hizbut Tahrir Indonesia (HTI), ${ }^{9}$ kemudian melakukan antisipasi radikalisme. Doktrin Agama Islam yang berlebihan (dengan pemahaman radikal) dapat menyebabkan tindakan terorisme ${ }^{10} \mathrm{di}$ tingkat perguruan tinggi dan lain sebagainya akan tetapi kabar terbaru Agustus 2019 terjadi penyerangan asrama mahasiswa berikut kata-kata rasis terhadap ras Papua di Surabaya dan Malang yang mana insiden ini mengakibatkan kerusuhan di Manokwari, Papua Barat.

Apabila kenyataanya demikian, maka apabila multikultur yang berada di Indonesia tidak mendapatkan perhatian yang sesuai maka tidak menutup kemungkinan akan berpotensi terhadap degradasi karakter nasionalis (moral) anak bangsa yang mana anak bangsa merupakan tumpuan ${ }^{11}$ kemajuan dan keutuhan bangsa ini kedepannya ${ }^{12}$.

Melihat pemapamaran diatas, peneliti tergelitik untuk menulis tentang pengaruh nilainilai multikultural terhadap karakter nasionalis santri yang berada di lingkungan pesantren. mengingat pesantren merupakan tempat multikultural.

\section{Nilai-nilai Multikultural}

Memahami kandungan UU No. 20 Tahun 2003 Pendidikan merupakan upaya nyata dengan perencanaan matang guna terwujudnya suasana dan pelaksanaan pembelajaran supaya peserta didik dapat aktif menggali dan mengembangkan potensi yang ada pada dirinya semisal kemampuan spiritual keagamaan, penguasaan diri, personaliti, kecerdasan, karakter baik, serta kreatifitas yang bermanfaat bagi diri, masyarakat, dan bangsa serta negara.

Indonesia memiliki pengembangan kewarganegaraan dan pengembangan budaya dengan corak masyarakat pluralisme. Hal ini ditandai dengan kemajemukan suku, ras, agama, adat setempat dan budaya. (Beni Susetyo, 2000:. 24). Bhineka Tunggal Ika merupakan sebuah konsep kekuatan untuk mempersatukan masayarakat Indonesia dengan kemajemukannya.

Multikultural yang ada di Indonesia harus mengesampingkan SARA dimana kelompok tertentu yang menganggap paling baik dari yang lain sehingga akan menimbulkan sebuah konflik bahkan perpecahan ${ }^{13}$. Konflik dapat dihindari jika rasa saling menghormati

\footnotetext{
${ }^{8}$ Imam Tholkhah, Membuka jendela pendidikan: mengurai akar tradisi dan integrasi keilmuwan [i.e. keiluan] pendidikan Islam (Divisi Buku Perguruan TInggi, RajaGrafindo Persada, 2004), 171.

9 Abu 'al-A 'la al-Maududi, Khilafah Dan Kerajaan: Evaluasi Kritis Atas Sejarah Pemerintahan Islam (Bandung: Mizan, 1998), 111-222.

10 Zuhairi Misrawi, Mira Rainayati, and Anjelita Noverina, Al-Quran kitab toleransi: tafsir tematik Islam rahmatan lil'âlamîn (Jakarta: Pustaka Oasis, 2010).

${ }^{11}$ Masnur Muslich, Pendidikan karakter: menjawab tantangan krisis multidimensional (Bumi Aksara, 2011), 1.

${ }_{12}$ Muhammad Anas Ma`arif, 'Internalisasi Nilai Multikulutural Dalam Mengembangkan Sikap Toleransi ( Studi Di Di Pesantren Mahasiswa Universitas Islam Malang)', Nazhruna: Jurnal Pendidikan Islam 2, no. 1 (24 March 2019), https://doi.org/10.31538/nzh.v2i1.179.

${ }^{13}$ Choirul Mahfud, Pendidikan Multikultural, Cet. 1 (Yogyakarta: Pustaka Pelajar, 2006), 240.
} 
dan menghargai dilakukan sehingga akan tercipta kerukunan antar peserta didik kelas XII Amanatul Ummah Mojokerto.

Multikulturalisme dipahami sebagai suatu sudut pandang yang titik tekannya pada interaksi. Dengan mempertimbangkan keadaan tiap budaya yang entititas memiliki kesetaraan haknya $^{14}$. Sebuah fakta yang tidak dapat dihindarkan dalam perbedaan dimana tidak menganggap unsur budaya yang dimiliki lebih berharga dari yang lain dan dihormati dalam derajat yang sama merupakan penerapan dalam pemahaman multikulturalisme ${ }^{15}$. Pendidikan harusnya menanamkan sikap, diajarkan dan diwariskan dalam peserta didik.

Nilai-nilai memiliki beberapa karakteristik $^{16}$ diantaranya yaitu; 1) Menerima perbedaan, 2) Percaya satu sama lain (mutual trust), 3) Menjaga kesepahaman (mutual understanding), 4) Menghargai satu sama lain (mutual respec), 5) Berpikir terbuka, 6) Mengapresiasi serta interdepensi, 7) Memulihkan perselisihan tanpa kekerasan.

a. Menerima perbedaan

Masing-masing siswa pasti mempunyai perbedaan bacgroun yang telah built in sebab dari awal proses pendidikan mulai dari keluarganya dan lingkungan tempanya bersosial. Tetapi, pendidikan semacam itu saat ini pada dasarnya belum secara maksmimal mengajarkan dan melakukan penanaman "kamampuan memaknai arti hidup dalam kebersamaan" dalam kelompok yang pluralis secara budaya, etnik, serta agama. Oleh karenanya selain dari ketiga pilar pendukung pendidikan nasional, yaitu how to know, how to do, how to be, dalam hal ini diperlukan penambahan pilar lainnya berupa how to live and work together.

Mengutip buku Learning: The Treasure Within Report, Delors, et. al menyatakan bahwasanya pilar pendidikan itu terdiri dari empat yakni learning to know (belajar agar tahu), learning to do (belajar agar dapat berbuat), learning to be (belajar untuk jadi manfaat), dan learning to live together, learning to live with others (belajar hidup dalam kebersamaan) ${ }^{17}$.

Learning to live together, learning to live with others dilakukan dengan cara menumbuhkan rasa pengertian terhadap orang lain dan mengapresiasi akan interdependensi menjalankan pekerjaan bersama-sama dan mencoba untuk menetralisis konflik senantiasa bersikap konsisten menghormati nilai-nilai keberagaman, saling mengerti dan cinta damai ${ }^{18}$.

14 Yaya Suryana, Pendidikan Multikulkultural: Suatu Upaya Penguatan Jati Diri Bangsa: Konsep-PrinsipImplementasi, Cet. I (Bandung: Pustaka Setia, 2015), 100.

15 Ammar Zainuddin and Juli Amaliya Nasucha, 'The Internalization of Sunan Drajat Social Concept in Multicultural Education Implementation', Al-Tadzkiyyah: Jurnal Pendidikan Islam 9, no. 1 (30 May 2018): 167-80, https://doi.org/10.24042/atjpi.v9i1.2958.

${ }^{16}$ H. A. R. Tilaar, Paradigma Baru Pendidikan Nasional, Cet. 1 (Jakarta: Rineka Cipta, 2000), 83; H.A.R Tilaar, Perubahan sosial dan pendidikan: pengantar pedagogik transformatif untuk Indonesia (Jakarta: Rineka Cipta, 2012$), 83$.

17 Harjali Harjali, 'URGENSI PENDEKATAN MULTIKULTUR DALAM PENDIDIKAN', Cendekia: Jurnal Kependidikan Dan Kemasyarakatan 9, no. 2 (19 December 2011): 214, https://doi.org/10.21154/cendekia.v9i2.876.

18 Nurbaiti Nurbaiti, Mundzier Suparta, and Taufik Abdillah Syukur, 'Character Building Through Reinforcement of Islamic Learning', TARBIYA: Journal of Education in Muslim Society 6, no. 1 (29 December 2019): 36-45, https://doi.org/10.15408/tjems.v6i1.10984. 
Baidhawy menegaskan bahwa praktiknya, untuk menanamkan pilar keempat kedalam proses pendidikan dapat melakukan langkah-langkah: Pertama, penumbuhan sikap simpati, empati, dan toleransi yang memang sebagai persyaratan awal untuk mendapatkan hasil koeksistensi dan proeksistensi dalam kemajemukan agama. Kedua, Antar agama saling berkomunikasi dan memberikan tawaran ssebuah perspektif nilai yang dimiliki dan dapat dikimpromikan. Ketiga, Kedewasaan emosional. Artinya, keharmonisan, toleransi, dan keleluasaan beraktivitas harusnya jalan bersama, seiring emosional yang semakin dewasa dalam kemitraan keagamaan. Keempat, Disamping mengakui akan hadirnya agama lain dan hak-hak beragama, agama perlu diposisikan pada tempat yang saling membuuhkan dan saling menguntungkan, dan sebab itulah agama bersifat kesetaraan. Kelima, Menjalankan sistem kontrak atau disebut kontrak kerjasama sosial untuk bersepakat hidup rukun antar ummat beragama. Maksud yang diingikan adalah, dengan perjanjian tersebut, ummat tersebut lebih memikirkan dampak positif yang akan ditimbulkan sehingga dapat hidup berdampingan untuk memajukan kehidupan bangsa dengan agama.

b. Percaya satu sama lain (mutual trust)

Rasa saling mempercayai adalah salah satu cara atau model bersosial yang penting untuk memperkuat budaya yang berkembang di masyarakat. Hal itu dapat diwujudkan berupa kumpulan norma atau kumpulan nilai informal yang dianut dan dipatuhi bersama oleh para individu masyarakat yang memang menghendaki terwujudnya kerjasama dengan orang lain. Selain sikap saling memberi kepercayaan, terdapat nilai lainnya yaitu iktikat baik, kemerdekaan bagi rakyat, sikap toleran, menghormati peraturan, dan lain sebagainya. Dengan adanya modal bersosial ini dapat dimanfaatkan juga sebagai fondasi sehingga terbangunnya rasionalitas berpikir logic, tidak mudah mencurigai, serta senantiasa berprasangka baik ${ }^{19}$.

\section{c. Menjaga kesepahaman (mutual understanding)}

Bersikap sepemahaman adalah perbuatan sadar akan nilai-nilai di tengah-tengah golongan yang bisa jadi berseberangan dan memungkinkan dapat saling menutupi kekurangan serta berkontribusi terhadap penambahan teman atau relasi dalam kehidupan. Pendidikan Islam sangat berperan serta bertanggungjawab membentuk landasan etik untuk saling memahami antar agama, etnik dan budaya yang plural, untuk mencerminkan sikap dan bentuk dari kepedulian akan sesama.

d. Menghargai satu sama lain (mutual respec)

Sikap ini mendudukkan manusia pada tingkat kesejajaran, tidak tampak superioritas ataupun inferioritas. Memberikan penghormatan dan penghargaan sesama manusia merupakan nilai keuniversalan semua macam agama di muka bumi. Pendidikan karakter Berbasis nilai Multikultur menumbuhkembangkan

19 Siti Maryam Munjiat, 'Peran Agama Islam Dalam Pembentukan Pendidikan Karakter Usia Remaja', AlTarbawi Al-Haditsah: Jurnal Pendidikan Islam 3, no. 1 (3 August 2018), https://doi.org/10.24235/tarbawi.v3i1.2954; Andika Aprilianto and Muhammad Arif, 'Pendidikan Islam Dan Tantangan Multikultural: Tinjauan Filosofis', Nazhruna: Jurnal Pendidikan Islam 2, no. 2 (11 August 2019): 279-89, https://doi.org/10.31538/nzh.v2i2.339. 
profesionalitas diri bahwa rasa damai membutuhkan sikap saling memberikan penghargaan antar pemeluk agama; dengan sikap tersebut, umat akan banyak mendengar kebaikan daripada membicarakan keburukan agama lain yang berbeda, dan menghargai harkat martabat golongan atau kelompok keagamaan lain yang beraneka ragam ${ }^{20}$.

\section{e. Berpikir terbuka}

Sebuah pendidikan seharusnya mengajarkan ilmu baru berkenaan cara berpikir dan berprilaku serta lebih dari itu hendaknya dapat menumbuhkan daya kreatifitas kepadda diri siswa-siswanya. Dengan mengambil pelajaran dari agama dan budaya lain, maka akan memberikan dampak positif kepada para siswa. setidaknya mereka akan dapat berperilaku lebih dewasa menyikapi perbedaan serta mereka senantiasa akan bersikap positif pula ketika mendapati realitas suatu perbedaan. Pendidikan karakter Berbasis Multikultural dapat mengontrol siswa saat berhadap-hadapn dengan pemandangan sosial yang plural, hal ini dicanangkan guna memulai pemahaman yang mendalam akan identitas diri, kehidupan dunia, ritual agama dan aktivitas budaya dirinya dan individu lain ${ }^{21}$.

f. Mengapresiasi serta interdependensi

Kelayakan hidup yang memanusiakan manusia akan terealisasi pada tatanan bersosial yang kepekaan kepeduliannya tinggi, yang mana semua sekumpulan masyarakat dapat dengan bebas menunjukkan penghargaannya dan melakukan pemeliharaan hubungan baik tersebut. Sikap mengapresiasi dan pemeliharaan hubungan baik, merupakan wujud dari saling ketergantungan positif. Disebabkan, sebagai makhluk social manusia tidak pernah akan survive kecuali dengan adanya ikatan sosial. Oleh karenanya pendidikan karakter sangat berperan yang diantaranya adalah menampakkan rasa peduli akan apresiasi dan interdependensi antar pengikut dan antar tradisi ritual agama-agama.

g. Memulihkan perselisihan tanpa kekerasan

Perselisihan atau konflik merupakan kenyataan yang tidak dapat dielakkan dan pasti akan terus terjadi baik di zaman yang telah lalu bahkan di zaman yang sedang dan akan dialami. (Zakiyuddin Baidhowy, 2005: 74) Akan tetapi, konflik yang dimaksud adalah yang dapat mengakibatkan kepada pengabaian nilai-nilai $u k h u w a h$ al-basyariah dan satu kesatuan universal manusia (unity of humand kind). Dalam keadaan konflik semacam ini, Pendidikan karakter diharapkan hadir untuk menyemangati dan saling menyokong kekuatan spiritual sebagai alat pengintegrasian dan kohesi sosial, dan dapat membawa angin segar atau sebagai pahlawan dalam menegakkan suasana yang damai.

${ }^{20}$ Thomas Lickona, Educating for Character: How Our Schools Can Teach Respect and Responsibility (New York: Bantam Books, 2009).

${ }^{21}$ James A. Banks and Cherry A. McGee Banks, eds., Multicultural Education: Issues and Perspectives, 7th ed (Hoboken, N.J: Wiley, 2010), 2. 
Pendidikan nilai-nilai multikultural yakni suatu pendekatan kepada pengajaran dan pembelajaran yang didasari oleh nilai dan kepercayaan yang demokrasi serta memandang keragaman pada sosial dan interpendensi dunia layaknya sebagian dari budaya yang plural.

Adapun nilai-nilai multikultural yang diterapkan di Madrasah Bertaraf Internasional (MBI) Amanatul Ummah adalah nilai 1) Memberi teladan, 2) Bekerjasama, 3) Menjaga kepercayaan, dan 4) Saling menghargai. (Dokumen Amanatul Ummah: 2018).

1. Memberi teladan, merupakan sikap modeling yang ampuh dalam mencontohkan dalam bersikap penghargaan terhadap perbedaan,

2. Bekerjasama adalah proses bersosial yang dapat mempersatukan perbedaan di kalangan peserta didik

3. Menjaga kepercayaan, dipraktikkan oleh kalangan siswa dengan pendidik ataupun siswa dengan sesama siswa yang lain dalam kehidupan sehari-hari di lingkungan sekolahan,

4. Saling menghargai, menunjukkan kepada penghormatan dan penghargaan tertinggi dalam kehidupan yang majemuk.

Ketepatan memilih nilai-nilai multikultural akan sangat mempengaruhi proses menumbuhkembangkan karakter peserta didik dalam bahasa lain, tingkat keberhasilan proses tersebut bergantung pada keseriusan segenap masyarakat lembaga dalam menaati dan mengamalkan nilai-nilai multikultural yang telah disepakati.

\section{Pendidikan Karakter Nasionalis}

Pendidikan karakter terambil dari kata "character", yang berartikan watak, tabiat, sifat kejiwaan, budi pekerti, kepribadian atau akhlak (Oxford). Perspektif teorinya, karakter manusia dapat diperhatika dari tiga bentuk, yakni: Mengetahui perbuatan baik (knowing the good), menyukai perilaku baik (loving the good), serta berbuat baik (doing the good). ${ }^{22}$ Pendidikan karakter meliputi pembiasaan perilaku yang baik untuk menjadi sebuah kebiasaan. Pengertian ini tidak sama dengan pengertian pendidikan moral (moral education) yang mana hanya menyatakan perbuatan yang baik. Di dalam kehidupan normal pendidikan moralitas hanya sebatas teori dan belum tentu menjadi sebuah kebiasaan tetapi juga tidak dapat dikesampingkan karena menjadi dasar dalam Pendidikan karakter ${ }^{23}$.

Penerapan dalam pendidikan karakter harus bersifat holistik. Hal ini tentunya dapat terlaksana dengan tingkat efektifitas dan efisensi yang sangat baik manakala keterlibatan semua pihak saling memberikan dukungan antara mereka ${ }^{24}$. Pendidikan karakter tidak hanya dilakukan di sekolah saja melainkan peran kedua orangtua dan keadaan masyarakat. Sekolah mempunyai peran sangat besar dalam pelaksanaan pendidikan karakter anak didiknya. Warga sekolah harus saling mendukung agar tercipta pendidikan karakter ${ }^{25}$. Peserta didik yang berfikir secara kritis dapat ditumbuhkan dengan peran guru sebagai role model. Dengan

22 Saptono, Dimensi-Dimensi Pendidikan Karakter: Wawasan, Strategi, Dan Langkah Praktis (Jakarta: Erlangga, 2012), 16-18.

${ }^{23}$ Hery Noer Aly, Watak Pendidikan Islam, 3rd ed. (Jakarta: Friska Agung Insani, 2008), 35.

24 AR Muhammad, Pendidikan Di Alaf Baru: Rekonstrukksi Atas Moralitas Pendidikan (Yogjakarta: Prismashopies Press, 2003), 133.

${ }^{25}$ Zainuddin Fananie, Pedoman Pendidikan Modern (Solo: Tiga Serangkai Pustaka Mandiri, n.d.), 26. 
paparan diatas maka pembelajaran melalui kegiatan dan metode pembelajaran yang bervariasi dapat dimasukkan dalam pendidikan karakter $^{26}$.

Sedangkan menurut Pengembangan Pendidikan Karakter (PPK) menurut keinginan pemerintahan sekarang ini, pendidikan karakter mengerucut kepada 5 (Lima) karakter inti, yaitu; 1) Karakter religius, 2) Integritas, 3) Nasionalis, 4) Gotong royong, dan 5) Mandiri. (Pedoman PPK, 2016:8-9). Dari kelima nilai karakter prioritas pemerintah tersebut, karakter nasionalis merupakan karakter yang ditumbuhkembangkan oleh Madrasah Aliyah Bertaraf Internasional (MBI) Amanatul Ummah Pacet-Mojokerto. Karakter tersebut dinilai sebagai karakter yang sangat integral dan tingkat urgensinya diperlukan sekali sebagai bekal peserta didik didalam membentengi keutuhan bumi pertiwi Indonesia tercinta.

Nasionalisme adalah sebuah kesadaran jiwa dan rasa kepercayaan yang dianut seluruh lapisan rakyat maupun tiap personalnya mereka kemudian membangun suasana kebangsaan yang masif didalam suatu wilayah di bawah naungan pemerintah, nasionalisme adalah rasa kebersamaan dalam satu asa kebangsaan ${ }^{27}$. Pengertian ini memberikan petunjuk, bahwa nasionalisme merupakan sebuah pemahaman yang membutuhkan perjuangan dan ditampilkan dalam pergerakan dalam satu komando visi dan misi serta bertujuan untuk kemaslahatan umum dalam kehidupan berbangsa dan bernegara.

Dengan bimbingan yang tepat, maka internalisasi karakter nansionalisme tentunya akan menghasilkan. Namun harus juga dibarengi dengan semangat dari dalam diri setiap peserta didik untuk mengaplikasikan karakter nasionalisme tersebut baik dilingkungan sekolah maupun di lingkungan keluarga dan masyarakatnya. Ada beberapa indikator ${ }^{28}$ untuk mengetahui seberapa kuat karakter yang dimiliki peserta didik khususnya karakter semangat kebangsaan atau karakter nasionalisme, di antaranya:

1. Kehadiran peserta didik dalam upacara memperingati hari-hari besar Nasional (hari pahlawan)

2. Berbahasa Indonesia dengan teman-teman sekelas meskipun berbeda etnik

3. Menghapalkan serta senang bernyanyi lagu-lagu kebangsaan dan perjuangan

4. Memiliki rasa kebanggaan akan keberagaman bahasa rakyat Indonesia

5. Ikut serta dalam memperingati hari pahlawan serta hari proklamasi kemerdekaan

6. Memiliki rasa cinta terhadap emajemukan ritual adat di Indonesia

7. Membela bangsa Indonesia di saat datang serangan yang mengancam Negara

8. Berargumen dan bertindak terkait kemajuin ekonomi Bangsa

${ }^{26}$ Muhammad Anas Maarif and Muhammad Husnur Rofiq, ‘Pola Pengembangan Kurikulum Pendidikan Pesantren Berkarakter: Studi Implementasi Pendidikan Berkarakter di Pondok Pesantren Nurul Ummah Mojokerto' 13 (2018): 16.

${ }^{27}$ Lukman Hakim, 'Nasionalisme Dalam Pendidikan Islam', Jurnal Pendidikan Islam 27, no. 2 (2016): 187-202; Ali Maschan Moesa, Nasionalisme Kiai: Konstruksi Sosial Berbasis Agama, Cet. 1 (Surabaya : Yogyakarta: IAIN Sunan Ampel Press ; LKiS : Distribusi, LKiS Pelangi Aksara, 2007), 137.

28 Firman Noor and Pusat Penelitian Politik (Indonesia), eds., Nasionalisme, Demokratisasi, Dan Identitas Primordial Di Indonesia (Jakarta: Lembaga Ilmu Pengetahuan Indonesia, Pusat Penelitian Politik, 2007); Retno Wihyanti, Slamet Subiyantoro, and Siti Sutarmi Fadhilah, 'Internalisasi Karakter Nasionalisme Dalam Kediversitasan Etnis Di Sekolah Dasar Islam', Edukasia: Jurnal Penelitian Pendidikan Islam 13, no. 1 (25 July 2018): 79-104, https://doi.org/10.21043/edukasia.v13i1.2881. 
9. Cakap berargumentasi dalam menjawab pertentangan kedaulatan bangsa

Karakter nasionalis secara mendasar, harus terpatri dalam sanubari siswa, sebab siswa tersebut kelak akan melanjutkan kepemimpinan Bangsa ini di masa yang akan datang. Dengan karakter nasionalisme itulah mereka akan membangun Bangsa. Pada intinya, tanpa adanya karakter nasionalis maka keniscayaan Indonesia menjadi Negara yang disegani Bangsa dan Negara lain akan sangat sulit diwujudkan.

\section{METODE}

Penelitian ini menggunakan penelitian kuantitatif. Peneliti menggunakan teknik survei dalam bentuk kuisioner. Kuisioner ini ditujukan untuk peserta didik kelas XII MBI Amanatul Ummah Mojokerto untuk mengetahui pengaruh nilai-nilai multikultural terhadap menumbuhkembangakan karakter nasionalisme. Metode analisa data memakai program SPSS (Statistical Package for Social Science).

Analisis liner berganda mempelajari pengaruh nilai-nilai multikultural (X1) terhadap variable $\mathbf{Y}$ (Pendidikan karakter), dengan model persamaan $\mathbf{Y}=\mathbf{a}+\mathbf{b}_{\mathbf{1}} \mathbf{X}_{\mathbf{1}}+\mathbf{C}_{\mathbf{i}}$. Koefisien determinasi dipakai untuk memahami variabel terikat apakah mempunyai hubungan dengan variabel bebas. Nilai koefisien determinasi yaitu antara 0 sampai 1, semakin mendekati 1 atau $100 \%$, maka semakin baik model regresi tersebut menjelaskan proporsi variasi variabel intervening atau berasal dari variabel bebas.

\section{PEMBAHASAN}

Madrasah Bertaraf Internasional Amanatul Ummah Mojokerto merupakan sekolah rujukan yang berada di kabupaten Mojokerto. Peneliti mengambil lokasi penelitian karena mempunyai latar belakang sikap menghormati dan menghargai multicultural.

\section{Uji Validitas}

Uji validitas di dalam kontkes ini tujuannyan untuk pengujian tingkat seberapa tepat penggunaan instrumen sebagai alat ukur variabel nilai-nilai multikutural dan Pendidikan karakter. Penjumlahan menggunakan uji validitas instrumen memanfaatkan analisa korelasi pearson. Rasionalitas mengenai butir item variabel yang menjelaskan valid dengan membandingkan nilai $r$ hitung dengan nilai $r$ tabel jika nilai $r$ hitung $>r$ tabel maka butir item diyakini valid. Berlandaskan hasil uji validitas intrumen dari dua variabel yaitu nilai-nilai multikulturalisme dan pendidikan karakter semuanya valid, sebab nilai $\mathrm{r}$ hitung (korelasi) lebih besar dari $r$ table.

\section{Uji Reabilitas}

Uji reabilitas instrumen tujuannya untuk mendapat pengetahuan tentang besaran indeks kepercayaan instrumen dari variabel nilai-nilai multikultural terhadap pendidikan karakter. Prasyarat suatu alat ukur mengindikasikan keampuhan yang semakin tinggi yakni jika koefisien reliabilitas $(\alpha)$ yang mendekati angka 1. Apabila koefisien alpha $(\alpha)$ lebih besar dari pada 0.6 maka alat ukur dianggap ampuh atau terdapat internal consistency reliability dan kebalikannya bila alpha lebih kecil dari 0.2 maka dianggap kurang ampuh atau tidak terdapat internal consistency reliability.

Berdasarkan hasil uji reliabilitas instrumen mengindikasikan bahwa kedua variabel yakni nilai-nilai multikultural serta pendidikan karakter ialah reliabel karena nilai r Alpha > 0,6.

\section{Analisis Regresi Linear}


Dari data menggunakan kuesioner yang sudah ditabulasi serta telah melalui analisis menggunakan analisa regresi linier berganda dengan menggunakan program SPSS dengan rumus $\mathrm{Y}=\mathrm{a}+\mathrm{b} 1 \mathrm{X} 1$. Maka $\mathrm{Y}=8,212+1,809 \mathrm{X}_{1}$. Konstanta sebesar 8,212, artinya adalah jika variabel nilai-nilai multikultural $(\mathrm{X} 1)=0$ maka pendidikan karakter (Y) diperkirakan akan mengalami kenaikan sebesar 8,212.

\section{Uji Koefisien Diterminasi}

Koefisien Determinasi (R2) yang menunjukan nilai sebesar 0,451. Keadaan tersebut menegaskan bahwa variabel nilai-nilai multikultural berpengaruh terhadap pendidikan karakter sebesar $45,1 \%$ adapun selebihnya $54,9 \%$ terdapat faktor lain yang mempengarui selain dari variabel dalam penelitian ini.

\section{Uji Hipotesis Parsial (T)}

Imam Ghozali (2006) menyatakan uji statistik t bertujuan untuk mengetahui seberapa berpengaruhnya satu variabel independen secara individual dalam menerangkan variabel dependen. Pengujian dilaksanakan dengan menggunakan signifikan level $0,05(\alpha=5 \%)$. Uji parsial (uji t) dipakai untuk mengetahui besarnya pengaruh dari masing-masing variabel independen secara parsial terhadap variabel dependen. Nilai t hitung X1 > t tabel $(6,425>2,012)$ maka sebagai konsekuensi ialah Ho ditolak Ha diterima untuk variabel di atas. Di dalam hal ini X1, dalam artian variabel nilai-nilai multikultural secara parsial berpengaruh signifikan terhadap pendidikan karakter.

\section{SIMPULAN}

Berpatokan pada hasil uji validitas instrumen dari kedua variabel yaitu nilai-nilai multikultural dan pendidikan karakter nasionalisme dalam diambil kesimpulan bahwa dari seluruh butir kesemuanya valid, dikarenakan nilai $r$ hitung (korelasi) lebih besar dari $r$ tabel. Dan hasil uji reliabilitas instrument menunjukkan kedua variabel yaitu nilai-nilai multikultural dan pendidikan karakter hasilnya reliabel karena nilai r Alpha > 0,6

Pengaruh nilai-nilai multikultural terhadap pendidikan karakter di Amanatul Ummah Mojokerto adalah sebagai berikut : Analisis koefisien determinasi (R2) yang menunjukan penilaian sebesar 0,451 . Hal ini berarti bahwa variabel nilai-nilai multikultural berpengaruh terhadap pendidikan karakter sebesar $45,1 \%$ serta sisahnya $54,9 \%$ terdapat faktor di luar variabel penelitian yang mempengaruhi.

Nilai thitung $\mathrm{X} 1>\mathrm{t}$ tabel $(6,425>2,012)$ dengan demikian konsekuensinya adalah Ho ditolak Ha diterima untuk variabel di atas. Dalam hal ini X1, artinya variabl nilai-nilai multikultural secara parsial berpengaruh signifikan terhadap pendidikan karakter.

\section{Daftar Pustaka}

Aly, Abdullah. Pendidikan Islam Multikultural Di Pesantren: Telaah Terhadap Kurikulum Pondok Pesantren Modern Islam Assalam Surakarta. Cet. 1. Yogyakarta: Pustaka Pelajar, 2011.

Aly, Hery Noer. Watak Pendidikan Islam. 3rd ed. Jakarta: Friska Agung Insani, 2008. 
Aprilianto, Andika, and Muhammad Arif. 'Pendidikan Islam Dan Tantangan Multikultural: Tinjauan Filosofis'. Nazhruna: Jurnal Pendidikan Islam 2, no. 2 (11 August 2019): 279-89. https://doi.org/10.31538/nzh.v2i2.339.

Aprilianto, Andika, and Wahyuni Mariana. 'Permainan Edukasi (Game) Sebagai Strategi Pendidikan Karakter'. Nazhruna: Jurnal Pendidikan Islam 1, no. 1 (5 September 2018): 139-58. https://doi.org/10.31538/nzh.v1i1.47.

Baisuki, Asror, and Ta'rif Ta'rif. 'Penanaman Karakter Moderat Di Ma'had Aly Situbondo'. EDUKASI: Jurnal Penelitian Pendidikan Agama Dan Keagamaan 15, no. 3 (31 December 2017). https://doi.org/10.32729/edukasi.v15i3.456.

Banks, James A., and Cherry A. McGee Banks, eds. Multicultural Education: Issues and Perspectives. 7th ed. Hoboken, N.J: Wiley, 2010.

Fananie, Zainuddin. Pedoman Pendidikan Modern. Solo: Tiga Serangkai Pustaka Mandiri, n.d.

Hakim, Lukman. 'Nasionalisme Dalam Pendidikan Islam'. Jurnal Pendidikan Islam 27, no. 2 (2016): 187-202.

Harjali, Harjali. 'URGENSI PENDEKATAN MULTIKULTUR DALAM PENDIDIKAN'. Cendekia: Jurnal Kependidikan Dan Kemasyarakatan 9, no. 2 (19 December 2011): 205-16. https://doi.org/10.21154/cendekia.v9i2.876.

Islam, Muhammad Hifdil. 'Tolerance Limitation in Facing Religious Diversity Based on the Teaching of Islam'. Nazhruna: Jurnal Pendidikan Islam 3, no. 1 (7 February 2020): 1-13. https://doi.org/10.31538/nzh.v3i1.483.

Lickona, Thomas. Educating for Character: How Our Schools Can Teach Respect and Responsibility. New York: Bantam Books, 2009.

Ma'arif, Muhammad Anas. 'Analisis Strategi Pendidikan Karakter Melalui Hukuman Preventif'. Ta'allum: Jurnal Pendidikan Islam 6, no. 1 (6 March 2018): 31-56. https://doi.org/10.21274/taalum.2018.6.1.31-56.

. 'Internalisasi Nilai Multikulutural Dalam Mengembangkan Sikap Toleransi ( Studi

Di Di Pesantren Mahasiswa Universitas Islam Malang)'. Nazhruna: Jurnal Pendidikan Islam 2, no. 1 (24 March 2019). https://doi.org/10.31538/nzh.v2i1.179.

Ma`arif, Muhammad Anas, and Muhammad Husnur Rofiq. 'The Role of Islamic Education Teachers in Improving the Character of Nationalism in Boarding School'. EDUKASI: Jurnal Pendidikan Islam 6, no. 1 (21 June 2018): 064-078. https://doi.org/10.5281/edukasi.v6i1.323.

Maarif, Muhammad Anas, and Muhammad Husnur Rofiq. 'Pola Pengembangan Kurikulum Pendidikan Pesantren Berkarakter: Studi Implementasi Pendidikan Berkarakter di Pondok Pesantren Nurul Ummah Mojokerto' 13 (2018): 16.

Mahfud, Choirul. Pendidikan Multikultural. Cet. 1. Yogyakarta: Pustaka Pelajar, 2006.

Malla, Hamlan Andi Baso. 'Pembelajaran Pendidikan Agama Islam Berbasis Multikultural Humanistik Dalam Membentuk Budaya Toleransi Peserta Didik Di SMA Negeri Model Madani Palu, Sulawesi Tengah'. INFERENSI: Jurnal Penelitian Sosial Keagamaan 11, no. 1 (1 June 2017): 163-86. https://doi.org/10.18326/infsl3.v11i1.163-186. 
Maududi, Abu 'al-A 'la al-. Khilafah Dan Kerajaan: Evaluasi Kritis Atas Sejarah Pemerintahan Islam. Bandung: Mizan, 1998.

Misrawi, Zuhairi, Mira Rainayati, and Anjelita Noverina. Al-Quran kitab toleransi: tafsir tematik Islam rahmatan lil'âlamîn. Jakarta: Pustaka Oasis, 2010.

Moesa, Ali Maschan. Nasionalisme Kiai: Konstruksi Sosial Berbasis Agama. Cet. 1. Surabaya: Yogyakarta: IAIN Sunan Ampel Press; LKiS : Distribusi, LKiS Pelangi Aksara, 2007.

Muhammad, AR. Pendidikan Di Alaf Baru: Rekonstrukksi Atas Moralitas Pendidikan. Yogjakarta: Prismashopies Press, 2003.

Munjiat, Siti Maryam. 'Peran Agama Islam Dalam Pembentukan Pendidikan Karakter Usia Remaja'. Al-Tarbawi Al-Haditsah: Jurnal Pendidikan Islam 3, no. 1 (3 August 2018). https://doi.org/10.24235/tarbawi.v3i1.2954.

Muslich, Masnur. Pendidikan karakter: menjawab tantangan krisis multidimensional. Bumi Aksara, 2011.

Noor, Firman, and Pusat Penelitian Politik (Indonesia), eds. Nasionalisme, Demokratisasi, Dan Identitas Primordial Di Indonesia. Jakarta: Lembaga Ilmu Pengetahuan Indonesia, Pusat Penelitian Politik, 2007.

Nugroho, Puspo. 'Internalization of Tolerance Values in Islamic Education'. Nadwa 12, no. 2 (7 January 2019): 197-228. https://doi.org/10.21580/nw.2018.12.2.2397.

Nurbaiti, Nurbaiti, Mundzier Suparta, and Taufik Abdillah Syukur. 'Character Building Through Reinforcement of Islamic Learning'. TARBIYA: Journal of Education in Muslim Society 6, no. 1 (29 December 2019): 36-45. https://doi.org/10.15408/tjems.v6i1.10984.

Rahmat, Rahmat. 'Model Pembelajaran Pendidikan Agama Islam Berlandaskan Multikultural (Telaah Implikasi Model Cooperative Learning Di Perguruan Tinggi)'. Jurnal Andragogi 1, no. 2 (14 November 2019): 68-85. http://riset.unisma.ac.id/index.php/ja/article/view/5290.

Raihani. Pendidikan Islam Dalam Masyarakat Multikultural. Cet. 1. Yogyakarta: Pustaka Pelajar, 2016.

Saptono. Dimensi-Dimensi Pendidikan Karakter: Wawasan, Strategi, Dan Langkah Praktis. Jakarta: Erlangga, 2012.

Suryadinata. Penduduk Indonesia. Jakarta: LP3ES, 2003.

Suryana, Yaya. Pendidikan Multikulkultural: Suatu Upaya Penguatan Jati Diri Bangsa: Konsep-Prinsip-Implementasi. Cet. I. Bandung: Pustaka Setia, 2015.

Tholkhah, Imam. Membuka jendela pendidikan: mengurai akar tradisi dan integrasi keilmuwan [i.e. keiluan] pendidikan Islam. Divisi Buku Perguruan TInggi, RajaGrafindo Persada, 2004.

Tilaar, H. A. R. Paradigma Baru Pendidikan Nasional. Cet. 1. Jakarta: Rineka Cipta, 2000.

Tilaar, H.A.R. Perubahan sosial dan pendidikan: pengantar pedagogik transformatif untuk Indonesia. Jakarta: Rineka Cipta, 2012.

Warsah, Idi. 'Pendidikan Keluarga Muslim Di Tengah Masyarakat Multi Agama: Antara Sikap Keagamaan Dan Toleransi (studi Di Desa Suro Bali Kepahiang-Bengkulu)'. 
Edukasia: Jurnal Penelitian Pendidikan Islam 13, no. 1 (25 July 2018): 1-24. https://doi.org/10.21043/edukasia.v13i1.2784.

Wihyanti, Retno, Slamet Subiyantoro, and Siti Sutarmi Fadhilah. 'Internalisasi Karakter Nasionalisme Dalam Kediversitasan Etnis Di Sekolah Dasar Islam’. Edukasia : Jurnal Penelitian Pendidikan Islam 13, no. 1 (25 July 2018): 79-104. https://doi.org/10.21043/edukasia.v13i1.2881.

Zainuddin, Ammar, and Juli Amaliya Nasucha. 'The Internalization of Sunan Drajat Social Concept in Multicultural Education Implementation'. Al-Tadzkiyyah: Jurnal Pendidikan Islam 9, no. 1 (30 May 2018): 167-80. https://doi.org/10.24042/atjpi.v9i1.2958. 